\title{
Ambalajı Açıldıktan Sonra Buzdolabında Depolanan İki Farklı Tütsülenmiş Balık Ürününün Mikrobiyal Kalite Değişimlerinin Gözlenmesi
}

\author{
Turgay Çetinkaya ${ }^{1 *}$, Zafer Ceylan ${ }^{2}$ \\ ${ }^{1}$ İstanbul Teknik Üniversitesi, Kimya Metalurji Fakültesi, Gıda Mühendisliği Bölümü, İstanbul, Türkiye (ORCID: 0000-0003-2962-1241) \\ ${ }^{2}$ Van Yüzüncü Yıl Üniversitesi, Su Ürünleri Fakültesi, İșleme Teknolojisi ABD, Van, Türkiye (ORCID: 0000-0002-6527-4382)
}

(İlk Geliş Tarihi 21 Kasım 2019 ve Kabul Tarihi 19 Aralık 2019)

(DOI: $10.31590 /$ ejosat.649379)

ATIF/REFERENCE: Çetinkaya, T. \& Ceylan, Z. (2019). Ambalajı Açıldıktan Sonra Buzdolabında Depolanan İki Farklı Tütsülenmiş Balık Ürününün Mikrobiyal Kalite Değişimlerinin Gözlenmesi. Avrupa Bilim ve Teknoloji Dergisi, (17), 982-988.

Öz

Günümüzde tütsülenmiş balık ürünleri tüketiciler tarafından yaygın olarak tercih edilmektedir. Ancak tütsülenmiş balık ürünlerinde özellikle ürünün ambalajı açıldıktan sonra mikrobiyal büyüme hızı artabilmektedir. Bu çalı̧ma ile Türkiye'de büyük marketlerde satılmakta olan iki farklı füme balık ürününün mikrobiyal değişimi 0., 12., 24., 36. ve 60. saatlerde izlenmiştir. Çalışmanın sonuçları, ambalajlar açıldıktan sonra buzdolabı koşullarında $\left(4 \pm 1{ }^{\circ} \mathrm{C}\right)$ saklanmasına rağmen füme balıklarında Toplam Mezofilik Aerobik Bakteri (TMAB), Toplam Psikrofilik Bakteri (TPB) ve Toplam Maya\&Küf (TMK) yükünün hızlıca yükseldiğini göstermiştir. Bu yüzden, çalışmanın sonuçlarına göre, ambalajların açılmasını takiben buzdolabı koşullarında saklanan füme Norveç Somonu (NS) ve Karadeniz Alası (KA) örneklerinin 36. saatten sonra tüketilmemesi önerilmektedir. Çünkü 36 saat sonra, tütsülenmiş NS ve KA için TMAB yükü sırasıyla $5.49 \log \mathrm{KOB} / \mathrm{g}$ ve $5.95 \log \mathrm{KOB} / \mathrm{g}$ değerlerine ulaşmıştır. TPB yükü ise tütsülenmiş NS ve KA örneklerinde sırasıyla $6.11 \mathrm{KOB} / \mathrm{g}$ ve $6.02 \mathrm{KOB} / \mathrm{g}$, olarak belirlenmiştir. $\mathrm{Bu}$ örneklerde TMK değerlerinde de yükselme olmasına rağmen bu değerlerin bakteriyel gelişmeye göre daha düşük olduğu tespit edilmiştir. Ancak 36 saat içinde, KA ürünlerinde TMK değerinin 5 log $\mathrm{KOB} / \mathrm{g}$ 'ın üzerine çıktı̆̆ görülmüştür. Öte yandan, 36. saatte NS ürünlerinin TMK değerinin ise $5 \mathrm{log} \mathrm{KOB} / \mathrm{g}$ 'dan daha az olduğu belirlenmiştir. Ayrıca, NS ve KA ürünlerinde duman aromasınının 24 saat sonunda kısmen kaybolduğu ve bazı bölgelerde örneklerin renginin değişerek yeşillenmeye başladığını gözlemlenmiştir. Bütün sonuçlar birlikte değerlendirildiğinde, özellikle tütsülenmiş balık ürünlerinin ambalajı açıldıktan sonra, ilk 24 saat içinde tüketilmesi tavsiye edilmektedir. Bu çalışma, tütsülenmiş balık ürünlerinde mikrobiyal bozulmayı önlemek için duman aromasını raf ömrü boyunca ambalaj içinde tutacak özelliklere sahip ambalaj kullanılması gerektiğini göstermiş̧ir. Buna ilaveten ambalaj içindeki balığın bozulma durumunu gösteren, bozulma sürecini geciktiren akıllı ve/veya aktif ambalaj uygulamaları üzerinde de çalışılması gerekmektedir.

Anahtar Kelimeler: Norveç Somonu, Karadeniz Alası, füme, mikrobiyal kalite, tüketici.

\section{An Observation of Microbial Quality Changes of Two Different Smoked Fish Products Stored at Refrigerator After Their Packages Being Opened}

\begin{abstract}
Smoked fish products are recently preferred by the consumers, but especially after their packages are opened, microbial growth of smoked fish may rapidly increase. In the present study, microbial growth of two different smoked fish products which are sold in local markets in Turkey, were monitored at 0., 12., 24., 36. and 60. hour (h) periods. As can be seen from the results of the study although the samples were stored at refrigerator conditions $\left(4 \pm 1^{\circ} \mathrm{C}\right)$, Total Mesophilic Aerobic Bacteria (TMAB), Total Psychrophilic Bacteria
\end{abstract}

* Sorumlu Yazar: İstanbul Teknik Üniversitesi, Kimya Metalurji Fakültesi, Gıda Mühendisliği Bölümü, İstanbul, Türkiye, ORCID: 0000-0003-29621241, cetinkayat@itu.edu.tr 
(TPB) and Total Yeast\&Mold (TYM) growth in smoked fish samples rapidly increased. Thus, with this study, it is advised that smoked Norway Salmon (NS) and smoked Black Sea Salmon (KA) samples opened and stored at refrigerator conditions should not be consumed after 36h. Because, 36h later, TMAB growth reached to $5.49 \log \mathrm{CFU} / \mathrm{g}$ and $5.95 \mathrm{log}$ CFU/g for smoked NS and KA, respectively. On the other hand, TPB counts of NS and KA smoked fish products were determined to be $6.11 \mathrm{log}$ CFU/g and $6.02 \mathrm{log}$ CFU/g, respectively. Though TYM growth was also found to be increased in these samples, it was slower as compared to the bacterial growth. However, within 36h, the TYM count of KA samples reached above $5 \log \mathrm{CFU} / \mathrm{g}$. On the other hand, the TYM count of NS samples was still lower than $5 \mathrm{log}$ CFU/g after 36h. Furthermore, it was observed that particularly smoke aroma was lost in the package and the colour of some parts started to be turned green for smoked NS and KA samples after 24h. Once all results were evaluated together, particularly, after the packages containing smoked fish products are opened, all smoked samples suggested to be consumed within $24 \mathrm{~h}$. The present study indicated that a package which has properties to keep the smoke flavor inside the package during shelf life should be used in order to delay the microbial spoilage in the smoked fish samples. In addition, smart and/or active packaging applications that indicate the deterioration or delay the deterioration process should also be studied.

Keywords: Norway Salmon, Black Sea Salmon, smoking, microbial quality, consumer.

\section{Giriş}

Balık eti zengin besin içeriği nedeniyle insan beslenmesinde önemli bir yere sahiptir. Ülkemizde deniz ürünleri gelişmiş ülkelere kıyasla az tüketilmesine rağmen, tüm su ürünleri arasında en çok balık ve balıktan üretilen işlenmiş ürünler tüketiciler tarafından tercih edilmektedir (Ceylan ve Unal, 2019). Öte yandan, işleme yöntemleri ve gıda muhafaza yöntemleri halk sağlı̆̆ açısından da son derece önemlidir. Uygun şartlar altında yapılmayan işleme yöntemi, ürün her ne kadar iyi muhafaza edilmiş olsa dahi, ürün kalitesini olumsuz yönde etkileyebilmektedir (Özkaya ve Cömert, 2008). Aslında balık yaşadığı ortam itibari ile en sağlıklı gıdalar arasında değerlendirilmektedir. Dahası literatüre bakıldığında balık eti anne sütü ile kıyaslanan gıda maddeleri arasında yer almaktadır. Fakat balık eti çabuk bozulabilen su ürünleri arasındadır (Külcü, 2017). Ayrıca, özellikle işleme yöntemlerine tabi tutulan ürünlerde işleme süresi boyunca, balık etinin mikrobiyal ya da kimyasal kalitesinde daha hızlı değişimler meydana gelebilmektedir (Meral ve diğ., 2019; Ceylan ve diğ., 2017).

Balık eti taze satışının yanı sıra çoğunlukla, dondurulmuş, konserve edilmiş ve füme olarak işlenmekte ve satılmaktadır. Füme ürünler, sıcak ya da soğuk dumanlama işlemine tabi tutularak duman aroması ile buluşturulabilirler (Yurchenko ve Mölder, 2005). Dahası, Stołyhwo ve Sikorski (2005)'e göre, füme prosesindeki üretim şartları ve duman konsantrasyonu ürünün raf ömrünü uzatmasının yanı sıra insan sağlığı üzerinde de pozitif etkide olabilmektedir. Füme teknolojinin uygulanışı esnansında ortaya çıkan tütsü içeriğindeki bileşiklerin gıda ile teması sonucunda bu bileşikler ürüne has lezzet verirken ürün üzerinde antimikrobiyal etki de sağlayabilmektedir. (Ertaş, 1998).

Türkiye'de füme balık tüketimi diğer Avrupa ülkelerine kıyasla daha azdır (Ceylan ve Şengör, 2015). Ancak, füme balık tadının tüketiciler tarafından keşfedilmesi ile tüketimi her geçen gün giderek artış göstermektedir. Öte yandan, tüketiciler özellikle füme ürünleri satın aldıkları sırada son kullanma tarihine ya da etiket üzerinde yazıyorsa üretim tarihlerine bakmaktadırlar. Ancak balık etinin kasaplık hayvan etlerine kıyasla daha hızlı bozulabildiği iyi bilinmektedir. Bu nedenle tüketiciler bu ürünleri satın aldıkları yani $4{ }^{\circ} \mathrm{C}$ 'deki soğuk muhafazadan çıkardıkları andan itibaren mikrobiyal gelişim hızla artabilmektedir.

Balık etinin bozulması renk, kıvam, koku ve lezzet açısından kendini gösterebilmekte, balığın kalitesini düşürmekte ve sonrasında tüketilme olanağını tamamen ortadan kaldırabilmektedir. Balık etindeki bozulma genel anlamda otoliz, oksidasyon, bakteriyel bozulma ve bu faktörlerin birlikte faaliyeti ile kendini gösterebilmektedir (İnal 1992; Küçüköner ve Küçüköner, 1990). Balıklarda özellikle Achromobacter, Bacillus, Clostridium, Escherichia, Flavobacterium, Micrococus, Proteus, Photobacterium cinsine ait bakteriler ile bazı mayaların bulunduğu tespit edilmiştir (Göktan, 1990). Norveç kaynaklı bazı balıklarda ise Enterobacteriaceae, Micrococcus, Lactobacillus, Vibrio, Coryneform ve Streptococcus cinsi bakterilerin de bulunabildiği ortaya konulmuştur (Ringo ve Strom, 1994). Yukarıda belirtilen çalışmaların yanı sıra balık etinde meydana gelen pek çok bozulma parametresi de mikrobiyal bozulma ile beraber ilişkilendirilmektedir (Getu ve diğ., 2015; Masette 1999). Ayrıca, gıda kaynaklı zehirlenme oranları da gözardı edilmeyecek düzeydedir. Bu nedenle, yaygın olarak tüketilen ürünlerdeki mikrobiyal değişimlerin ortaya konularak tüketicilerin bilgilendirilmesi önem arz etmektedir.

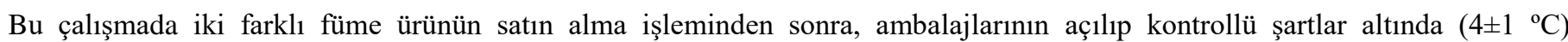
depolanmasını takiben üründe TMAB, TPB ve TMK gelişimlerinin belirli saat aralıklarında izlenmesi amaçlanmıştır.

\section{Materyal ve Metot}

\subsection{Materyal}

Gıda materyali olarak, markette $4{ }^{\circ} \mathrm{C}$ 'de soğuk dolapta sunulan kısımdan satın alınan, içeriği Karadeniz Alası eti (Salmo trutta labrax), tuz ve odun dumanından oluşan balık ürünü ve meşe ağacı aroması ile elde edilen talaşta "soğuk" fümelenmiş, içeriği Somon balığg eti (Salmo salar), tuz ve odun dumanından oluşan balık ürünü kullanılmıştır (n=3). 


\subsection{Metot}

\subsubsection{Mikrobiyolojik Analizler}

Sunulan çalışmada, TMAB, TPB ve TMK sayımları gerçekleştirilmiştir. Çalıșma süresince $10^{1}$ 'den $10^{81} \mathrm{e}$ kadar hazırlanan dilüsyondan $1 \mathrm{~mL}$ örnek alınarak steril petrilerin içerisine aktarılmış, üzerine Plate Count Agar (PCA, Merck-VM888763 930) besiyerinin dökülmesi ve çalkalama işlemini takiben petriler soğumaya bırakılmıştır. TMAB sayısı, 0., 12., 24., 36. ve 60. saat ekim yapılan petrilerin $35^{\circ} \mathrm{C}$ 'ye ayarlanmış inkübatörde (Memmert, D-91126, Schwabach FRG, Germany) 24-48 saat inkübe edilmesi ile tespit edilmiştir. TPB'deki değişimi tespit etmek için, ekim yapılan petri kapları $7{ }^{\circ} \mathrm{C}^{\prime}$ ye ayarlanmış inkübatörde (Memmert, D-91126, Schwabach FRG, Germany) 10 gün boyunca inkübe edilmiştir. TMAB ve TPB analizleri yukarıda belirtilen açıklamalara bağlı kalarak FDA (Food and Drug Administration) bakteriyolojik analitik el kitabında yer alan Maturin ve Peeler (1998) yöntemine göre gerçekleştirilmiştir. TMK sayısı için ise Dichloran Rose Bengal Agar (DRBC, Merck-VM330966 142) besiyeri petrilere dökülerek petriler soğumaya bırakılmıştır. Aynı şekilde analiz süresince $10^{1}$ den $10^{81} \mathrm{e}$ kadar hazırlanan dilüsyonlardan $0,1 \mathrm{~mL}$ örnek alınarak steril petrilerin içerisine aktarılarak yayma plak yöntemi ile ekim işlemi gerçekleştirilmiştir. Petriler inkübatörde (Memmert, D-91126, Schwabach FRG, Germany) $23{ }^{\circ} \mathrm{C}$ sıcaklıkta 5 gün süresince inkübe edilmiştir (Anon, 2005).

\subsubsection{Istatistiksel Analiz}

Elde edilen veriler ANOVA testine tabi tutularak örneklerdeki soğuk depolama süresince meydana gelen farklılıklar istatistiksel olarak değerlendirilmiştir. JMP (SAS Campus Drive, USA Versiyon 14) istatistik yazılım programı gruplar arasındaki ve depolama saatleri (0., 12., 24., 36. ve 60. saatler) arasındaki istatistiksel önem farkını ortaya koymak için kullanılmıştır. Gruplar ve depolama saatleri arasındaki istatistiksel önem fark1 Student's t-Test ile ortaya konulmuş olup, bu istatistiksel önem fark1 $p<0.05$ ile gösterilmiştir.

\section{Araştırma Sonuçları ve Tartışma}

NS ve KA örneklerine ait TMAB, TPB ve TMK sonuçları ve bunların istatistiksel olarak yorumlanmasına ait veriler Tablo 1 ve 2'de sunulmuştur.

Tablo 1. NS'de depolama süresine bağlı TMAB, TPB ve TMK sayısında (log KOB/g) meydana gelen mikrobiyal değişimler.

\begin{tabular}{ccccccc}
\hline & Ürün & \multicolumn{4}{c}{ Depolama Süresi (Saat) } \\
\cline { 3 - 6 } TMAB & & 0. & 12. & 24. & 36. & 60. \\
TPB & & $3.29 \pm 0.02^{\mathrm{D}}$ & $4.04 \pm 0.37^{\mathrm{C}}$ & $4.40 \pm 0.11^{\mathrm{C}}$ & $5.49 \pm 0.16^{\mathrm{B}}$ & $7.57 \pm 0.03^{\mathrm{A}}$ \\
& NS & $3.49 \pm 0.06^{\mathrm{E}}$ & $4.82 \pm 0.13^{\mathrm{D}}$ & $5.70 \pm 0.10^{\mathrm{C}}$ & $6.11 \pm 0.03^{\mathrm{B}}$ & $7.58 \pm 0.16^{\mathrm{A}}$ \\
TMK & & $2.20 \pm 0.28^{\mathrm{D}}$ & $3.04 \pm 0.37^{\mathrm{C}}$ & $3.98 \pm 0.04^{\mathrm{B}}$ & $4.37 \pm 0.52^{\mathrm{B}}$ & $5.80 \pm 0.13^{\mathrm{A}}$
\end{tabular}

A, B, C, D, E depolama süresine bağlı olarak NS’ye ait örneklerdeki farkın istatistiksel olarak önemli olduğunu tanımlar $(p<0.05)$.

Tablo 2. KA'da depolama süresine bağlı TMAB, TPB ve TMK sayısında (log KOB/g) meydana gelen mikrobiyal değişimler.

\begin{tabular}{|c|c|c|c|c|c|c|}
\hline \multirow[b]{2}{*}{ TMAB } & \multirow{2}{*}{ Ürün } & \multicolumn{5}{|c|}{ Depolama Süresi (Saat) } \\
\hline & & $\begin{array}{c}0 . \\
2.93 \pm 0.29^{\mathrm{C}}\end{array}$ & $\begin{array}{c}12 . \\
4.67 \pm 0.47^{\mathrm{B}}\end{array}$ & $\begin{array}{c}24 . \\
5.65 \pm 0.49^{\mathrm{A}}\end{array}$ & $\begin{array}{c}36 . \\
5.95 \pm 0.03^{\mathrm{A}}\end{array}$ & $\begin{array}{c}60 . \\
6.11 \pm 0.06^{\mathrm{A}}\end{array}$ \\
\hline TPB & KA & $3.26 \pm 0.06^{\mathrm{C}}$ & $3.62 \pm 0.54^{\mathrm{C}}$ & $5.20 \pm 0.01^{\mathrm{B}}$ & $6.02 \pm 0.23^{\mathrm{C}}$ & $6.65 \pm 0.25^{\mathrm{C}}$ \\
\hline TMK & & $2.52 \pm 0.35^{\mathrm{C}}$ & $3.16 \pm 0.08^{\mathrm{BC}}$ & $3.28 \pm 0.39^{\mathrm{B}}$ & $5.45 \pm 0.21^{\mathrm{A}}$ & $5.57 \pm 0.04^{\mathrm{A}}$ \\
\hline
\end{tabular}

A, B, С, D, E depolama süresine bağlı olarak KA'ya ait örneklerdeki farkın istatistiksel olarak önemli olduğunu tanımlar $(p<0.05)$.

\subsection{Toplam Mezofilik Aerobik Bakteri (TMAB) Gelişimi}

İki farklı işlenmiş füme ürünün TMAB (0. saat) başlangıç yükü sırası ile NS ve KA örnekleri için $3.29 \log \mathrm{KOB} / \mathrm{g}$ ve $2.93 \log$ $\mathrm{KOB} / \mathrm{g}$ olarak tespit edilmiştir. TMAB yükü açısından her iki ürünün de başlangıç bakteri yükünün uygun limitlerde olduğu ve ürünlerin yüksek kalitede olduğu tespit edilmiştir. Literatürde tütsüleme işlemi ile gıda materyali üzerinde önemli düzeyde bakterisidal ve/veya bakteriyostatik aktivitenin ortaya konulabileceği Kolsarıcı ve Güven (1998) tarafindan belirtilmiştir. Yani dumanlama işlemi balık eti üzerinde proses öncesinde bulunabilecek bakteriler üzerinde öldürücü ya da en azından bakteri sayısındaki artı̧̧1 engelleyen bir faktördür. Daha önceki çalı̧̧malara bakıldığında taze balık örneklerinin (çipura (3.78 log KOB/g: Ünal Şengör ve diğ., 2018), levrek (2.92 $\log \mathrm{KOB} / \mathrm{g}$ : Ceylan ve diğ., 2017), alabalık (3.11 $\log \mathrm{KOB} / \mathrm{g}$ : Meral ve diğ., 2019)) TMAB yükünün, çalışmamızda kullanılan füme ürünlerin başlangıç TMAB yüküne logaritmik olarak eşdeğer bulunması dumanın bakterisidal ve/veya bakteriyostatik etkisini göstermektedir. Kaba ve diğ. (2012)'ye göre, balıklara uygulanan dumanlama işleminin TMAB yükünün azaltılmasında etkili olabileceği düşünülmektedir. Ancak dumanın bu etkilerinin ürünün raf ömrünü çok uzatmayacağını ve ürün e-ISSN: 2148-2683 
ambalajının tüketici tarafından açılması ile bu etkilerin hızlı bir şekilde ortadan kalktığını sunulan bu çalışma göstermiştir. Öyle ki, depolamanın daha 12. saatinde yapılan analizde NS örneklerinde bu değerin $4.04 \log \mathrm{KOB} / \mathrm{g}$ 'a çıktığ 1 ve aynı zamanda bir önceki analiz saatinin sonucuna kıyasla bu farkın istatistiksel olarak da önemli olduğu $(p<0.05)$ ortaya konulmuştur. Benzer sonuçlar KA örneklerinin TMAB sayısında da ortaya konulmuş olup burada da bakteri yükü $2.93 \log \mathrm{KOB} / \mathrm{g}$ 'dan 12. saatin sonunda $4.76 \log$ $\mathrm{KOB} / \mathrm{g}$ 'a çıkmıştır $(p<0.05)$. Soğuk depolamanın 24. saatinde yapılan analizde ise NS örneklerinin TMAB sayısı $4.40 \log \mathrm{KOB} / \mathrm{g}$ olarak değerlendirilirken 12. saate kıyasla gruplar arasında istatistiksel bir fark bulunamamıştır $(p>0.05)$. Öte yandan, KA örneklerinin TMAB sayısı daha hızlı bir artışla $5.65 \log \mathrm{KOB} / \mathrm{g}$ değerine ulaşmış olup, bir önceki saatin analiz sonucu ile oluşan farkın istatistiksel olarak önemli olduğu ortaya konulmuştur $(p<0.05)$. Dahası depolamanın ilerleyen saatlerinde (36. ve 60. saat) KA örneklerinin ulaştığı değerler arasında istatistiksel bir fark tespit edilmezken, 60. saatte KA örneklerin TMAB sayısı $6.11 \log \mathrm{KOB} / \mathrm{g}$ değerine ulaşmıştır. KA örneklerine kıyasla, NS ürününde de 36. ve 60. saatlerde yapılan değerlendirmelerde TMAB gelişiminin hızlı bir şekilde devam ettiği ve depolamanın 60. saatinde TMAB sayısının $7.57 \mathrm{log} \mathrm{KOB} / \mathrm{g}$ değerine ulaştı̆̆ tespit edilmiştir. Dahası bu ürünün TMAB yükünün soğuk depolamanın her saatinde artı̧̧ gösterdiği ve bu artışın her bir analiz saatinde elde edilen sonuçlarda istatistiksel olarak önemli olduğu ortaya konulmuştur $(p<0.05)$. Buna göre iki ürünün mikrobiyal yüklerindeki farklıllğın ürünlerin kendisinden kaynaklandığı söylenebilir. Ayrıca ürünün et kalınlığı ile mikrobiyal kalite ilişkilendirilebilmektedir. Literatüre bakıldığında da Agbodaze ve diğ. (2005)'e göre et kalınlığının mikrobiyal kalite ile ilişkilendirilebileceği bildirilmiştir (Agbodaze ve diğ., 2005). Ayrıca Şekil 1'den de görülebileceği gibi, özellikle soğuk depolamanın 36. saatinde her iki ürün görsel olarak da tüketilemez olarak tanımlanmıştır. Bu bağlamda TMAB sayısındaki artış ürünü koku ve renk olarak özellikle etkilemiştir.

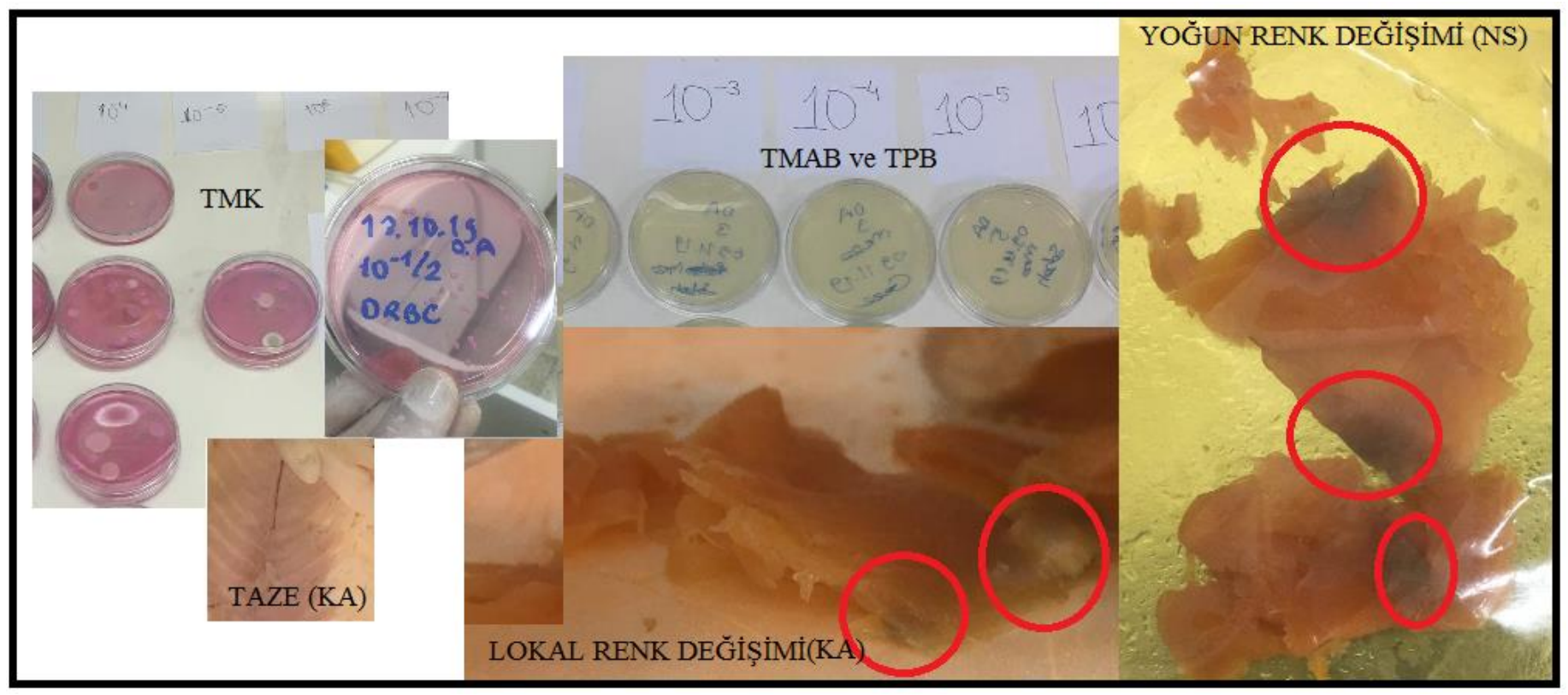

Şekil 1. Mikrobiyal yüke bağl1 olarak KA'da (ortada) ve NS'de (sağda) değişen görsel renk değişimleri.

ICMSF (1986) tarafindan 6 log KOB/g mezofilik bakteri sayısı genellikle kabul edilebilirlik değerinin sınır değeri olarak tanımlansa da KA'da $5.95 \log \mathrm{KOB} / \mathrm{g}$, NS'de ise $5.49 \log \mathrm{KOB} / \mathrm{g}$ değeri ile ürünlerin inceliği, renk değişimleri ve kokuları bir arada değerlendirildiklerinde ambalajları açıldıktan sonra 36. saat itibari ürünlerin tüketilemeyeceği ortaya konulmuştur. Ancak, Şekil 2'den de görülebileceği üzere, KA için mikrobiyal artı̧ hızı özellikle 0. saatten 12. saate geçişte gerçekleşirken, NS'de ise bu saatteki mikrobiyal yük artı̧ı nispeten daha düşüktür. 


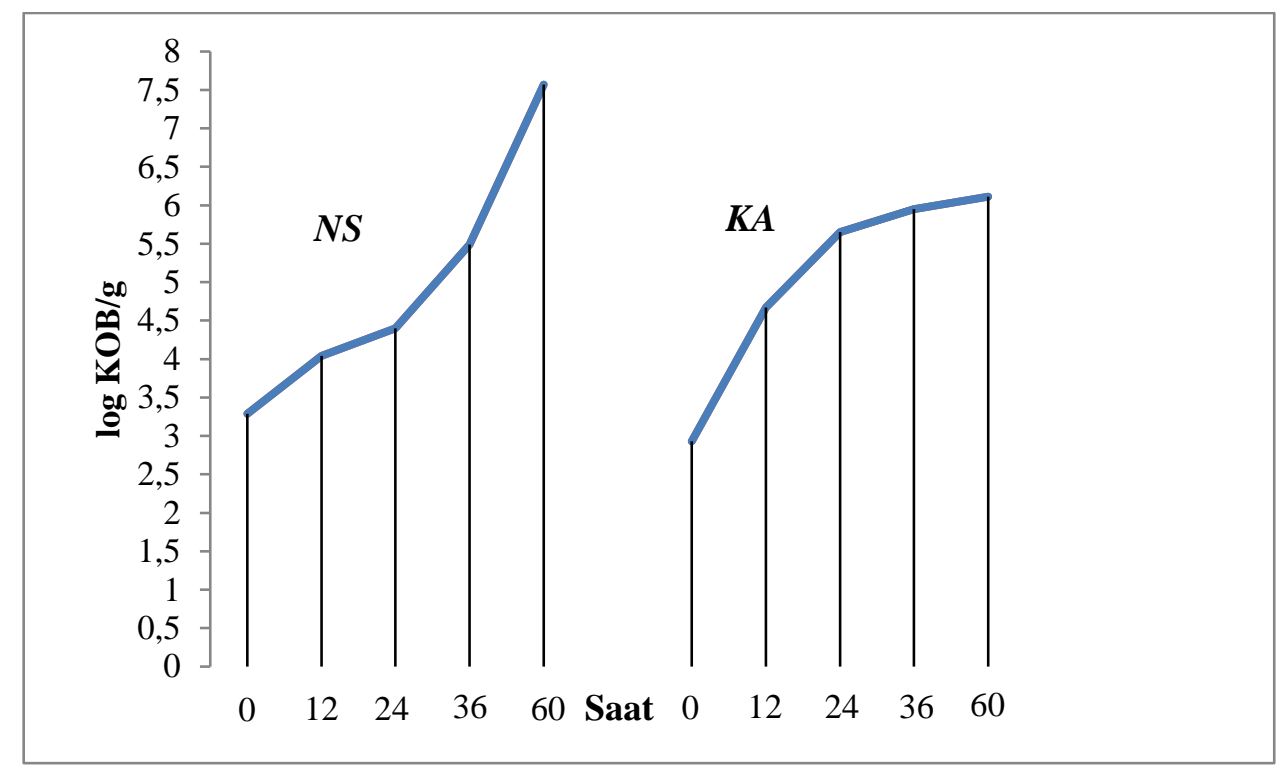

Şekil 2. TMAB gelişimi ( $\mathrm{n}=3)$.

\subsection{Toplam Psikrofilik Bakteri (TPB) Gelişimi}

Her iki üründe de TPB sayısı depolama süresiyle artmıştır. Meral ve diğ. (2019)'a göre balığımsı kokunun oluşumundan ve bozulmadan sorumlu olan psikrofilik bakteriler soğuk muhafaza sıcaklığında da kolay bir şekilde üreyebilmektedir. Bu bağlamda çalışma sonuçlarımıza bakıldığında da NS örneklerinin TPB sayısındaki artış hızı istatistiksel olarak da tüm depolama süreleri arasında önemli bulunmuştur $(p<0.05)$. Özellikle depolamanın 24 . saatinde $(5.70 \mathrm{log} \mathrm{KOB} / \mathrm{g})$ yapılan analiz sonuçlarının 0 . analiz saati (3.49 $\log \mathrm{KOB} / \mathrm{g}$ ) ile kıyaslandığında artış hızı diğer analiz periyotlarına kıyasla daha yüksek bulunmuştur. NS ve KA örneklerinin başlangıç psikrofilik bakteri yüküne kıyasla, mezofilik bakteri yükü daha düşüktür. Başka bir ifade ile TPB yükü TMAB den daha yüksektir. Bunun sebebi ise çok iyi şartlar altında yapılamayan işleme, ayıklama süreçleri ve sanitasyon koşulları nedeni ile ham materyalin kontamine olabilmesine bağlanmaktadır. Bu durumlarda yüksek psikrofilik bakteri sayısının oluşabildiği Thatcher ve Clark (1978) tarafından da ortaya konulmuştur. Balık etindeki psikrofilik bakteri sayısındaki artış aynı zamanda etteki kötü koku, acı, ransit efektlerden sorumludur (Jay, 2000). Bu bağlamda NS örneklerine göre KA örneklerinde TPB sayısındaki artış hızı eğilimi Şekil 3'ten de görülebileceği üzere daha yavaştır. Bu durum ürünün et kalınlığının NS'ye göre fazla olması, başlangıç yükünün NS örneklerine kıyasla daha düşük olması ile de ilişkilendirilebilir. TPB yönünden çalışma sonuçları göstermiştir ki ambalajı açılan ve soğuk muhafazada saklanan NS ve KA örneklerini tüketicinin özellikle depolamanın ilk 24 saati içinde tüketmesi tavsiye edilir.

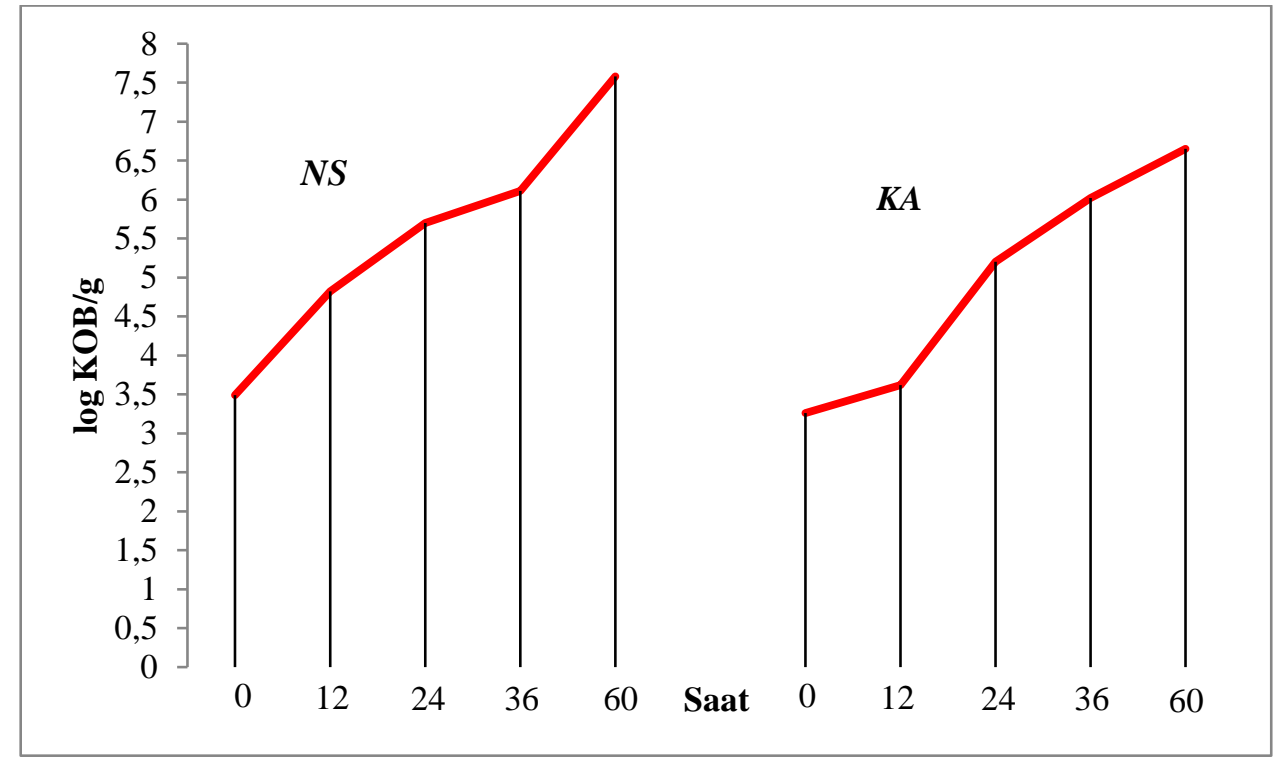

Şekil 3. TPB gelişimi $(n=3)$.

\subsection{Toplam Maya-Küf (TMK) Gelişimi}

Gıda ve gıda materyalleri steril değildir, bu nedenle bakteri ve virüslerin yanı sıra maya ve küfler gıdalarda Stagnitta ve diğ. (2006)'ya göre 5 log KOB/g'ye kadar bulunabilmektedir. Sunulan çalışma sonuçları değerlendirildiğinde TMAB ve TPB yükü 60. saat sonunda 7.57 ve $7.58 \mathrm{log} \mathrm{KOB} / \mathrm{g}$ değerlerine kadar ulaşabilirken, TMK sayısı ise 60. saat sonunda NS ve KA gruplarında sırası ile 
5.80 ve $5.57 \log \mathrm{KOB} / \mathrm{g}$ değerlerinde bulunmuştur. Dutta ve diğg. (2018) de soğuk depolama periyodu boyunca füme yapılmış balık etindeki TMK sayısının artış kaydedebileceğini ortaya koymuştur. Ayrıca aynı araştırmada bakteriyel gelişimin yanı sıra tam kontrollü şartlar altında yapılmayan prosesler sonucunda maya-küf gelişiminden dolayı füme yapılmış balıketlerinin tüketilmesi önemli düzeyde sağlık sorunlarına yol açabileceği ortaya konulmuştur. Ayrıca El-Lahamy ve diğg. (2018) tarafından ortaya konulmuştur ki füme işlemi balık etindeki hali hazırda var olan bakteri gelişiminin yanı sıra, maya\&küf miktarını önemli düzeyde (2.30 log $\mathrm{KOB} / \mathrm{g}^{\prime}$ dan $\left.1.0 \log \mathrm{KOB} / \mathrm{g}^{\prime} \mathrm{a}\right)$ düşürebilmektedir. Bu açıdan NS ve KA füme örneklerindeki maksimum TMK sayısının yanı sıra artış hızının en yüksek olduğu saat dilimi bu çalışma ile ortaya konmuştur. Bu sonuçlardan ve Şekil 4 'ten de görülebileceği üzere, NS örneklerinde daha yavaş bir artış tespit edilirken, KA örneklerinde özellikle depolamanın 24. saatinden 36. saatine geçiş periyodu arasında önemli düzeyde bir artı̧ kaydedilmiştir. Hatta bu fark istatistiksel olarak da önemli bulunmuştur $(p<0.05)$. Ayrıca paketi açılmış örneklerin arasında oluşabilecek TMK miktarlarının ürünlerde kullanılan tuz ve duman konsantrasyonu farklılıklarından veya dumanın ette ne kadar penetre edebildiğine bağlı olarak değişebildiği öngörülmektedir. Bu bağlamda ambalajı açılmış bir füme balık ürününün tüketimine bağlı olarak insan vücuduna geçebilecek MK riskini engellemek adına ürünlerin özellikle 24. saate kadar olan tüketimlerinin daha uygun olabileceği böylece potansiyel sağlık risklerinin daha da azaltabileceği ortaya konmuştur. Bir başka açıdan ise üreticiler hali hazırda kullandıkları fümeleme yöntemlerine ek olarak Ceylan ve diğ. (2017) tarafindan ortaya konulan nanoenkapsüle edilmiş sıvı duman formatı ile kontrollü salınım ve dumanın balık eti üzerinde daha geniş yüzeye temas etme imkânı sağlanmıştır. Böylece, buradaki sunulan çalışma sonuçlarından da anlaşılacağı üzere dumanın etkinliği paket açıldıktan sonra hızlı bir şekilde kaybolmaktadır. Ancak nanokapsüllenen materyal tüketiciye daha uzun süreli aroma sunabilirken, aynı zamanda TMK gelişimini de daha uzun vadede sınırlama imkânı sağlayabilmektedir.

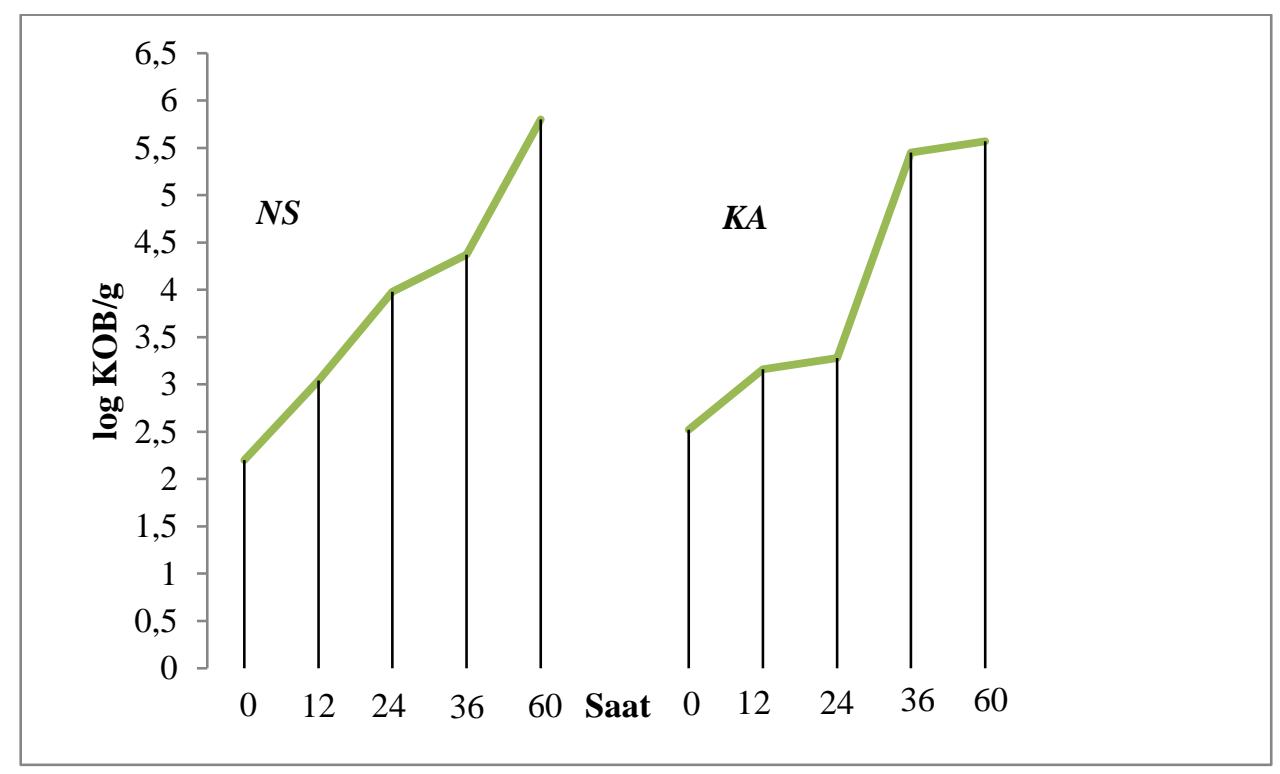

Şekil 4. TMK gelişimi $(\mathrm{n}=3)$.

\section{Sonuç}

Ülkemizde su ürünleri tüketimi düşük olmasına rağmen son yıllarda özellikle işlenmiş balık ürünlerine olan ilginin arttığı bilinmektedir. Bu bağlamda özellikle füme ürünler de yaygın olarak tercih edilmektedir. Bazen tüketici ürünün bir miktarını tüketmekte, ambalajı açılan ürünün kalanını daha sonra tüketmek üzere buzdolabına kaldırmaktadır. Bu bağlamda üründe nasıl ve ne kadar bir mikrobiyal gelişim meydana geldiği bilinememektedir. Bu çalışma ile Türkiyede büyük marketlerde satışta olan ve iki farklı füme balık ürünün mikrobiyal gelişimi ambalajı açıldıktan sonraki 60. saate kadar izlenmiştir. Sonuç olarak NS örneklerinin TMAB gelişimi 0. saate kıyasla özellikle depolamanın 36. saatinde yüksek oranda artarken, TPB üremesi ise 24. saatte ve TMK sayısındaki artış ise soğuk depolamanın 36. saatinde neredeyse başlangıç yükünü logaritmik olarak ikiye katlamaktadır. KA örneklerinde ise; TMAB gelişimi depolamanın 36. saatinde başlangıç yüküne kıyasla neredeyse iki katı artmıştır. TPB sayısı yine 0. saate kıyasla depolamanın 36. saatinde, TMK gelişimi ise, özellikle depolamanın 36. saatinde başlangıç yüküne kıyasla iki katından fazla artış sergilemiştir. Bu sonuçlar göstermektedir ki tüm mikrobiyal kalite parametreleri bir arada değerlendirildiğinde her iki ürünün de 36 . saatten sonra tüketimleri uygun görülmemektedir. En iyi tüketim süresinin ise paketin açılmasını takiben ilk 24 saat içerisinde olması gerektiği tavsiye edilmektedir. Ayrıca bu saat aralığından sonra füme ürün aroması da hızlı bir şekilde ürünü terk etmektedir ve ürün zaten özelliğini de kaybedebilmektedir.

\section{Teșekkür}

Bu çalı̧sma İstanbul Teknik Üniversitesi Bilimsel Araştırma Projeleri Koordinasyonu Birimi tarafindan desteklenen Doç. Dr. Filiz ALTAY'ın yürütücüsü, Turgay ÇETINKKAYA ve Dr. Öğr. Üyesi Zafer CEYLAN'ın araştırmacısı olduğu MDK-2019-42144 numaralı projenin kurgulanmasına yönelik bir ön deneme çalışmasıdır. Bu bakımdan yazarlar proje yürüttücüsünün bilgileri dahilinde gerçekleştirilen bu çalışma için Doç. Dr. Filiz ALTAY'a ve İTÜ BAP Birimi’ne teşekkür eder. 


\section{Kaynakça}

Agbodaze, D., Nmai, P. N. A., Robertson, F. C., Yeboah-Manu, D., Owusu-Darko, K., \& Addo, K. K. (2005). Microbiological quality of "khebab" consumed in the Accra metropolis. Ghana medical journal, 39(2), 46-49.

Anon, 2005, Merck Gıda Mikrobiyolojisi Uygulamaları Sayfa 358. Ed: A.K. Halkman, Başak Matbaacılık Ltd Şti Ankara.

Ceylan, Z., \& Şengör, G. (2015). Dumanlanmış Su Ürünleri ve Polisiklik Aromatik Hidrokarbonlar (PAH's). Gıda ve Yem Bilimi Teknolojisi Dergisi, (15).

Ceylan, Z., Sengor, G. F. U., Sağdıç, O., \& Yilmaz, M. T. (2017). A novel approach to extend microbiological stability of sea bass (Dicentrarchus labrax) fillets coated with electrospun chitosan nanofibers. LWT-Food Science and Technology, 79, 367-375.

Ceylan, Z., Sengor, G. F. U., \& Yilmaz, M. T. (2017). A novel approach to limit chemical deterioration of gilthead sea bream (Sparus aurata) fillets: Coating with electrospun nanofibers as characterized by molecular, thermal, and microstructural properties. Journal of food science, 82(5), 1163-1170.

Ceylan, Z., \& Unal, K. (2019). The Effect of Different Thawing Methods on Quality Parameters of Frozen Mussels and Shrimp Meats. Turkish Journal of Agriculture-Food Science and Technology, 7(6), 927-933.

Dutta, M., Majumdar, P. R., \& Islam RUl, S. D. (2018). Bacterial and Fungal Population Assessment in Smoked Fish during Storage Period. J Food Microbiol Saf Hyg, 3(127), 2476-2059.

El-Lahamy AA, El-Sherif SA, Khalil KI, Mahmud AA (2018) Effect of Smoking Methods and Refrigeration Storage on Microbiological Quality of Catfish Fillets (Clarias gariepinus). J Food Ind Microbiol 4: 127. doi:10.4172/2572-4134.1000127.

Ertaş, A.H. (1998). Tütsünün Bilesimi. Gıda Teknolojisi, 23 (3): 177-185.

Getu, A., Misganaw, K., \& Bazezew, M. (2015). Post-harvesting and major related problems of fish production. Fisheries and Aquaculture Journal, 6(4).

Göktan, D. (1990). Gıdaların Mikrobiyal Ekolojisi-Et Mikrobiyolojisi. Cilt I., Ege Üniv., Basımevi, Bornova, İzmir.

ICMSF, 1986, International commission on microbiological specifications for foods, sampling plans for fish and shellfish. In: ICMSF, Microorganisms in foods. Sampling for microbiological analysis: Principles and scienctific applications (2nd Edition). University of Toronto Press, Toronto, Canada, 181-196.

İnal, T., "Besin hijyeni hayvansal gıdaların sağlık kontrolü”, Final Ofset A.Ş. (Genişletilmiş 2. baskı), İstanbul, 345-592 (1992).

Jay, J. M. (2000). Food preservation with modified atmospheres. 283: 205. INDR Hoidnian led. Modern Food Microbiology.

Kaba, N., Özer, Ö., \& Corapc1, B. (2012). The determination of some quality parameters of smoked gar fish meat balls. Journal of FisheriesSciences. com, 6(4), 357-367.

Kolsarıc1, N., \& Güven, T. (1998). The effects of using liquid smoke on storage stability of frankfurters. Turkish Journal of Veterinary and Animal Sciences, 22(4), 379-388.

Küçüköner, E., \& Küçüköner, Z. (1990). Balık mikroflorası ve balıklarda meydana gelen mikrobiyal değişmeler. GIDA, 15(6).

Külcü, D. B. (2017). Farklı sıcaklıklarda muhafaza edilen palamut (sarda sarda) balığının bazı kimyasal kalite niteliklerinin belirlenmesi. Sakarya Üniversitesi Fen Bilimleri Enstitüsü Dergisi. Doi, 10.

Masette M. 1999. A comparative study of storage tissue of warm and cold water fish in view of the current market demands. A PhD thesis, United Nations University, UNU- Fisheries training programme.

Maturin, L. J., \& Peeler, J. T. (1998). Aerobic plate count. Ch. 3. Food and Drug Administration Bacteriological Analytical Manual, 8.

Meral, R., Ceylan, Z., \& Kose, S. (2019). Limitation of microbial spoilage of rainbow trout fillets using characterized thyme oil antibacterial nanoemulsions. Journal of Food Safety, 39(4), e12644.

Özkaya, F. D., \& Cömert, M. (2008). Gida zehirlenmelerinde etken faktörler. Türk Hijyen ve Deneysel Biyoloji Dergisi, 65(3), 149158.

Ringø, E., \& Strøm, E. (1994). Microflora of Arctic charr, Salvelinus alpinus (L.): gastrointestinal microflora of free-living fish and effect of diet and salinity on intestinal microflora. Aquaculture Research, 25(6), 623-629.

Stagnitta, P. V., Micalizzi, B., Guzmán, D., \& Stefanini, A. M. (2006). Prevalence of some bacteria yeasts and molds in meat foods in San Luis, Argentina. Central European journal of public health, 14(3).

Stołyhwo, A., \& Sikorski, Z. E. (2005). Polycyclic aromatic hydrocarbons in smoked fish-a critical review. Food Chemistry, 91(2), 303-311.

Thatcher, F.S. and Clark, D.S. 1978. Microorganisms in foods. ICMSF Academic Press, New York.

Ünal Şengör, G. F., Balaban, M. O., Ceylan, Z., \& Doğruyol, H. (2018). Determination of shelf life of gilthead seabream (Sparus aurata) with time temperature indicators. Journal of Food Processing and Preservation, 42(2), e13426.

Yurchenko, S., \& Mölder, U. (2005). The determination of polycyclic aromatic hydrocarbons in smoked fish by gas chromatography mass spectrometry with positive-ion chemical ionization. Journal of Food Composition and Analysis, 18(8), 857-869. 